\title{
En dannet mann
}

\author{
Doktoravhandlingen til Stefán Hjörleifsson er en kritisk tilnærming til Islands gigantiske og internasjonalt \\ prestisjetunge genprosjekt deCODE. Debatten som fulgte ble ikke akkurat noe sokratisk ordskifte. \\ Opphavsmann og direktør for deCODE er farbroren hans.
}

Fredag ettermiddag i et solmyldrende Bergen. På det avtalte møtestedet er dørene stengt. Vi går gatelangs på leting etter et fredelig sted for samtale og en matbit. «Her er det bra,» sier Stefán Hjörleifsson. Barn i fri dressur løper mellom bordene, klatrer på benkene og slår frydefullt med designbestikket hos kokkene Bølgen\&Moi. Fredelig er et relativt begrep. Stefán Hjörleifsson har seks hjemmeboende barn.

\section{Moralsk gangsyn}

Han startet på medisinstudiet i Reykjavik som 19-åring. Etter første semester avgjorde eksamensresultatene hvem som fikk fortsette, 150 studenter konkurrerte om 36 plasser. Stefán Hjörleifsson ble nummer én.

- En fryktelig erfaring. Ekkelt. Det var første gangen jeg vant noe som helst, og bare fordi jeg hadde pugget som en gal - kjemi, cellebiologi, embryologi, fysiologi og anatomi. Jeg tenkte: Er det dette jeg må briljere med? Så meldte jeg overgang til filosofi. - Fant du det du søkte?

- Det jeg lærte der gjorde meg i stand til å se hva jeg hadde reagert så sterkt på og savnet. Jeg fikk et analyseverktøy, et språk. Aristoteles benytter et kunnskapsbegrep som skiller mellom episteme, techne og phronesis. Episteme betyr vitenskap, techne er teknologi, phronesis er moralsk gangsyn. Kunnskapen skal være gavnlig for formålet. Legestudiet er proppet fullt med teoretisk kunnskap og tekniske ferdigheter. Deretter forventes det at vi nærmest intuitivt skal være i stand til å anvende det vi har lært til pasientens beste. I allmennpraksis er verktøyene tid og rom for det individuelle, vi utvikler av nødvendighet en viss menneskekunnskap. Spesialistene i sykehusene løper bokstavelig talt en større risiko i en hverdag mer preget av teknologi. Men også for kirurgen handler det om å gjøre det riktige, til riktig tid og for riktig person.

Stefán Hjörleifsson snakker perfekt norsk, men noe er annerledes. Han uttrykker seg i hele setninger. Hadde jeg ikke visst bedre, ville jeg ha skrevet hans langsomme tempo og omhyggelige diksjon på kontoen for forsiktighet og kontroll. Hvem vet forresten? Og er det ikke slik at flere med fordel kunne ha tenkt først, og deretter tatt seg bryet med å formulere hele setnin- ger? Det sies om Stefán Hjörleifsson at han har en dannet form for avslappet kontroll som han aldri legger fra seg.

- Medisinsk etikk må ikke begrense seg til å diskutere enkeltsaker som abort og informert samtykke. Vi må utvikle vårt moralske gangsyn slik at det står i forhold til den teoretiske og tekniske kompetansen som jo er formidabel, sier han.

Nå er Stefán Hjörleifsson tilbake på Island med jevne mellomrom som universitetslektor i medisinsk etikk ved universitetet i Reykjavik. De nye legene skal få del i den kunnskapen han selv savnet. - Er det et snev av idealisme som driver deg?

- Akkurat det er ren idealisme. Oppdraget kommer på toppen av to travle jobber og krevende familielogistikk her hjemme. Dessuten taper jeg penger hver gang.

I tillegg er han en av initiativtakerne til Filosofisk poliklinikk som inviterer til samtaler og debatt om komplekse faglige og etiske spørsmål. Høstens møteserie er viet nettopp spørsmålet «Hvordan blir leger til?».

\section{You can worry yourself to death}

Stefán Hjörleifsson disputerte for doktorgraden i 2008 med avhandlingen «Genetics, risk and medicalization. A case study of preventive genetic technologies in Iceland».

- Jeg er bekymret over teknologiske nyvinninger som fører til at stadig flere mennesker blir diagnostisert som pasienter og risikanter. deCODE er et storslått eksempel på forskning som driver en slik utvikling videre. I mitt doktorgradsarbeid analyserte vi blant annet begrepsdannelse og retorikk, hvordan genetikk og prediktive tester ble omtalt i mediene og hvilken betydning prosjektet ble tillagt i den offentlige debatten. Dessuten var jeg nysgjerrig på hvilke betraktninger forskerne i deCODE selv gjorde seg. Jeg fikk anledning til å følge utviklingen fra orkesterplass og på et veldig tidlig tidspunkt.

«A global leader in human genetics. Advancing unique products and services based on unrivalled capabilities for analyzing and understanding the genome.» Slik presenterer deCODE seg selv på hjemmesiden. Prediktive tester er det kommersielle produktet det satses tyngst på, ikke minst gjennom det publikumsrettede deCODEme. For 2000 amerikanske dollar får du som kunde tilsendt utstyr for enkel prøvetaking fra munnslimhinnen, sender prøven i en ferdig frankert konvolutt til Reykjavik og får kort tid etter tilgang til en personlig nettside som viser din relative risiko for mer enn 50 sykdomstilstander. Siste nytt i skrivende stund er at kreft i bukspyttkjertelen nå er lagt til menyen: «Pancreatic cancer has a poor prognosis. Knowing your genetic risk can raise your awareness of this rare and deadly cancer.»

- Jeg har alltid tenkt på islendingene som et stoisk folk, herdet gjennom historien og med en verdig innforståtthet overfor døden. Er det ikke et paradoks at nettopp Island slår seg opp som global salgsagent for produkter som spekulerer i angst og illusjoner om å lure skjebnen?

- Paradokset var der før deCODE. Moderniteten kom mye senere til Island enn til resten av Norden, folk bodde i jordhus for 100 år siden. Etter den annen verdenskrig endret alt seg veldig raskt, vi ble nyrike og ekspansive. Dagens Island er først og fremst preget av entreprenørskap og utsikten til raske penger. Min farbror, Kári Stefánsson, grunnla deCode med fandenivoldsk selvtillit og risikovillig kapital fra USA.

- Hva med forskningens kår i et slikt prosjekt?

- Investorene forventet salgbare resultater. Raskt. På en måte var det en gavepakke til meg at deCODEme, med sin aggressive markedsføring av consumer genetics, ble lansert rett før min disputas. Dilemmaene ble veldig synlige. Gode forskere følte nok at de hadde solgt sjelen sin med deCODEme. De forsto at publikum manglet forutsetninger for å forstå informasjonen de hadde kjøpt. "You can worry yourself to death,» sa en ambivalent seniorforsker til meg.

\section{Vinr er sás vörnuð̉ býdr}

«Venn er den som advarer» lyder et islandsk ordtak. Stefán Hjörleifsson har med de beste hensikter gått i strupen på livsverket til sin farbror.

- Kom han til disputasen?

- Nei. Ikke alt i denne prosessen egner seg på trykk. Jeg tror jeg har navigert 


\section{Stefán Hjörleifsson}

Født på Island 1968

- Bachelorgrad i filosofi, Universitetet på Island, 1992

- Cand.med., Universitetet i Bergen, 1998

- Dr.med., Universitetet i Bergen, 2008

- Fastlege i Bergen, 2006 -

- Universitetslektor i medisinsk etikk, Universitetet på Island, 2007 -

- Førsteamanuensis i allmennmedisin, Universitetet i Bergen, 2008 -

Stefán Hjörleifsson og datteren Ellisif Helga. Foto Marit Hommedal/SCANPIX

rimelig avansert $i$ et vrient farvann. Det var mitt valg ikke å forske utenfra. Jeg gikk til ham og spurte, han slapp meg inn og var hjelpsom. Men i den offentlige debatten om deCODEme, rett før disputasen, gikk han $\mathrm{i}$ harnisk og brukte alle midler i pressen til å latterliggjøre og nedverdige meg. Han truet med å anmelde meg til ulike instanser også, men meg bekjent ble det aldri noe av. - Skremmende?

- Jeg var veldig, veldig forberedt. Når jeg hadde tatt en doktorgrad på dette prosjektet, skulle det bare mangle at jeg ikke ga noe tilbake, til mine informanter og til allmennheten. Mitt arbeid er vitenskapelig etterrettelig. Husk at jeg aldri har angrepet forskningen som sådan, den har jeg stor respekt for. - Du nevnte begrepsdannelse. Hva fant du i så måte?

- deCODE var uhyre treffsikre i sin retorikk. De spilte på det islandske selvbildet, «vi vet hvem vi er». Det falt selvsagt sammen med deres eget behov for informasjon fra slektsforskning og klinisk virksomhet. I etterkant er det slående hvordan mediene overtok et språk og en implisitt forståelse som koblet genetikk til forventningene om bedret folkehelse og fortjeneste. Motstemmene ble ignorert. Det hele bar preg av en slags newspeak.

Stefán Hjörleifsson identifiserer seg ikke med sine eplekjekke landsmenn. Han finner deres selvsikkerhet på grensen til det ufordragelige. Om seg selv sier han at han snarere har et skjørt selvbilde. Jeg tror ham. Hans doktorarbeid, ikke minst fortellingen om det, er like fullt - og derfor i enda større grad - et uvanlig og viktig vågestykke i et ellers ikke altfor risikovillig akademi.

- Jeg skulle ønske jeg kunne få noen flinke fjernsynsfolk til å lage en dokumentar om deCODEme, sier han.

\section{Paradis}

Stefán Hjörleifsson kommer fra en katolsk familie. Uvitende som jeg er, blir jeg over- rasket. Islandsk katolikk? Dessuten lattermild over at han faktisk bor i Paradis.

- På 1930-tallet konverterte en del islandske kunstnere til katolisismen, blant dem den islandske forfatteren Halldór Laxness og min onkel som var skuespiller. Det er forresten han som har lært meg det jeg kan om å opptre foran forsamlinger. Jeg hadde forferdelig sceneskrekk, fikk helt jernteppe. Min onkel lærte meg å puste. Folk kan få det bedre hvis de kan puste. - Med andre ord mer en kulturkrets enn et trossamfunn?

- Helt klart. Troen betyr ikke mye for meg, men jeg fikk med meg en ærbødighet for livet og døden og et alvor i forhold til de store spørsmål. Møtet med den norske statskirken var for øvrig interessant. Min kone er protestant. Da vi skulle gifte oss, ville ikke kirken i Sandnes foreta vielsen fordi jeg var katolikk. Vi ble til slutt viet i den katolske kirken i Bergen.

Kanskje katolikker puster friere likevel?

Stefán Hjörleifsson har altså seks barn i alderen 2-18 år med samme dame. Han synes ikke det er spesielt slitsomt, men er nøye med å presisere at de har vært heldige som har fått friske barn. Stefán Hjörleifsson deltar til alt overmål i maratonkarusell på den uforklarlige fritiden sin. Det er grunn til å tro at mannen liker å utfordre seg selv. En kollega og venn beskriver barna hans som selvgående og glade. Familien har ikke fjernsyn, men utstyr for å vise film. Foreldrene er hjemme på skift så langt som råd er. Han vil gjerne snakke om barna, men nøler litt.

- Dette er litt vanskelig å si, jeg vil gjerne høre hva du synes, men jeg tror altså at vi er over gjennomsnittet flinke til å oppdra barn. - Javel?

- Jeg må ty til de ulike kunnskapsformene igjen. Barna er skoleflinke, spiller instrumenter og driver idrett på høyt plan slik legebarn ofte gjør. Men det er ikke koketteri når jeg sier at de først og fremst er snille og har moralsk forstand. I noen grad kan det å drive barn frem stå i motsetning til å skape gavnlige og lykkelige mennesker. Min kone og jeg er bevisste på å gi mest støtte på moral. Vennskap og godhet teller mer enn prestasjoner.

- Er seks barn noe man bestemmer seg for, eller finner de bare veien til en katolikk i paradis?

- Vi merket vel at dette fikk vi til. Etter det fjerde barnet trodde jeg egentlig vi var enige om at det var nok, så jeg steriliserte meg. Da jeg kom hjem, fikk jeg så mye pepper at det nesten ble skilsmisse. Komplikasjoner etter inngrepet fikk jeg også, jeg gikk hjulbeint som en cowboy i to måneder. Det var kjempevondt, og stemningen hjemme var laber. Så skrapte jeg sammen 15000 kroner på en skarve stipendiatlønn for å bli reoperert på en privat klinikk, mot alle mine prinsipper. Den eneste trøsten var at plastikkirurgen som foretok inngrepet, brukte lønnen fra privatklinikken til å finansiere opplæring av kolleger i Afrika. Det fikk meg til å føle meg litt bedre.

Nevnte jeg at Stefán Hjörleifsson er en modig mann? Dertil sjenerøs. Historier om reproduktivt besvær og ufrivillig komikk er sosial kapital som kvinner vanligvis forvalter og utveksler over vinglassene. Levert av en mann stiger verdien betraktelig.

\section{Epilog}

På flyplassen dagen etter får jeg vite at Norges utenriksminister er rammet av en sjelden sykdom. Nyheten ledsages av et kraftig forstørret nærbilde av statsrådens hender, tatt mens han utfører et offisielt oppdrag. Utenriksdepartementet kan bekrefte overfor Se og Hør at Jonas Gahr Støre lider av vitiligo. Apropos diagnoser, phronesis og behovet for dannelse.

\section{Elisabeth Swensen}

elswense@online.no Tidsskriftet 